\title{
EFEKTIFITAS LAYANAN KONSELING KELOMPOK DENGAN PENDEKATAN CLIENT CENTERED UNTUK MENINGKATKAN KEPERCAYAAN DIRI PADA SISWA KELAS VIII SMP N 16 YOGYAKARTA TAHUN AJARAN 2018/2019
}

\author{
Siti Komariyah ${ }^{(1)}$, Iis Lathifah Nuryanto ${ }^{(2)}$ \\ Program Studi Bimbingan dan Konseling \\ Fakultas Keguruan dan Ilmu Pendidikan \\ Universitas PGRI Yogyakarta \\ E-mail: skomariyah1994@ gmail.com
}

\begin{abstract}
Abstrak
Tujuan penelitian ini adalah untuk mengetahui efektifitas layanan konseling kelompok dengan pendekatan client centered untuk meningkatkan kepercayaan diri pada siswa kelas VIII SMP N 16 Yogyakarta. Jenis penelitian yang digunakan dalam penelitian ini adalah pre-eksperimental dengan jenis one group pre-test post-test design. Subyek penelitian yaitu siswa kelas VIII SMP N 16 Yogyakarta yang berjumlah 7 siswa yang dipilih dengan metode purposive sampling technique. Metode pengumpulan data menggunakan angket. Teknik analisis data dengan menggunakan analisis statistik uji-t antar ulangan. Hasil penelitian menunjukkan hipotesis terbukti bahwa layanan konseling kelompok pendekatan client centered dapat meningkatkan kepercayaan diri siswa kelas VIII SMP N 16 Yogyakarta tahun pelajaran 2018/2019. Dari hasil uji $\mathrm{t}$ diperoleh nilai $\mathrm{t}=20,297$ dengan nilai $\mathrm{p}=0,000<0,05$ yang berarti ada peningkatan kepercayaan diri siswa antara sebelum dan sesudah diberikan layanan konseling kelompok dengan pendekatan client centered. Pemberian layanan konseling kelompok menggunakan pendekatan client centered efektif dalam upaya meningkatkan kepercayaan diri siswa.
\end{abstract}

Kata kunci: layanan konseling kelompok, client centered, kepercayaan diri

\begin{abstract}
The purpose of this study was to determine the effectiveness of group counseling services with $a$ client centered approach to increase confidence in eighth grade students of SMP N 16 Yogyakarta. This type of research used in this study is pre-experimental with the type of one group pre-test post-test design. The research subjects were 7th grade students of SMP N 16 Yogyakarta, totaling 7 students who were selected using the purposive sampling technique. The data collection method uses a questionnaire. Data analysis technique was using a statistical analysis of t-test between replications. The results showed a proven hypothesis that client centered approach group counseling services could increase the confidence of eighth grade students of SMP N 16 Yogyakarta in the 2018/2019 academic year. From the t test results obtained $t$ value $=20.297$ with $p=0.000<0.05$ which means there is an increase in student confidence between before and after group counseling services are provided with a client centered approach. Providing group counseling services using an effective client-centered approach in an effort to increase student confidence.
\end{abstract}

Keywords: group counseling services, client centered, self confidence

\section{Info Artikel}

Diterima September 2019, disetujui Oktober 2019, diterbitkan Desember 2019 


\section{PENDAHULUAN}

Pendidikan sebagai upaya memanusiakan manusia pada dasarnya adalah upaya mengembangkan kemampuan potensi individu sehingga memiliki kemampuan hidup optimal baik sebagai pribadi mamupun sebagai anggota masyarakat serta memiliki nilai-nilai moral religious dan sosial sebagai pedoman hidupnya. Tentu saja, pendidikan juga dipandang sebagai usaha yang bertujuan untuk mendewasakan anak. Kedewasaan intelektual, sosial dan moral, tidak semata-mata kedewasaan dalam arti fisik.

Pendidikan adalah proses sosialsisai untuk mencapai kopetensi pribadi dan sosial sebagai dasar untuk mengembangkan potensi dirinya sesuai dengan kapasitas yang dimilikinya dalam mengisi berbagai peran dan pekerjaan dimsayarakat.

Undang-undang sistem pendidikan Nasional No. 20 Tahun 2003 bahwa tujuan pendidikan adalah untuk mengembangkan potensi manusia agar menjadi manusia yang beriman dan bertakwa kepada tuhan yang maha Esa, berakhlak mulia, sehat, berilmu, cakap, kreatif, mandiri dan menjadi warga Negara yang demokratis serta bertanggung jawab.

Program sekolah sebagai lembaga pendidikan formal tidak sekedar bermaksud mengembangkan aspek intelektual saja. Sekolah didirikan untuk membantu keluarga dalam mengarahkan pertumbuhan dan perkembangan anak agar menjadi siswa seutuhnya. Pembentukan pribadi menjadi manusia seutuhnya akan dapat diwujudkan jika siswa memperoleh kesempatan menghayati kehidupan manusia, baik secara umum maupun khusus sebagai suatu bangsa. Pengalaman itu sebagian diperoleh siswa di sekolah, dalam pelaksaan pendidikan dan pengajaran di sekolah masih banyak siswa yang mengalami berbagai macam hambatan dalam belajar.

Hambatan dalam belajar ini perlu dituntaskan agar siswa dapat belajar dengan baik dan nyaman sehingga memperoleh prestasi yang lebih baik. Mengatasi berbagai kesulitan atau hambatan belajar, siswa sering kali membutuhkan bimbingan dari orang lain. Bimbingan yang dilakukan di sekolah yaitu oleh guru bimbingan dan konseling (BK). Salah satu hambatan atau masalah yang dihadapi siswa adalah percaya diri yang rendah. Rasa percaya diri pada usia remaja merupakan hal yang sangat penting, karena pada saat itu remaja seharusnya mantap dalam mengambil sebuah keputusan dan tidak mudah terpengaruh, tidak tergantung orang lain, dan yakin terhadap kemampuan sendiri.

Belajar adalah perubahan tingkah laku, hanya berbeda cara atau uasaha pencapaiannya. Penelitian ini menitik beratkan pada interaksi anatara individu dengan lingkungan. Melalui interaksi inilah terjadi serangkaian pengalaman belajar. Belajar memiliki beberapa maksud antara lain, mengetahui suatu keperibadian, kecakapan atau konsep yang sebelumnya tidak pernah diketahui, dapat menjelaskan sesuatu yang sebelumnya tidak dapat diperbuat, baik tingkahlaku maupun keterampilan.

Masa remaja merupakan salah satu masa dilewati dalam setiap perkembangan individu. Masa perkembangan remaja adalah periode dalam perkembangan individu yang merupakan masa mencapai kematangan mental, emosional, sosial, fisik, dan pola peralihan dari kanak-kanak menuju dewasa (Hurlock,1991; Malahyati, 2010; Fitri dkk, 2018).

Wedan (2016) Terdapat sejumlah karakteristik yang menonjol pada anak usia SMP yanki terjadinya ketidakseimbangan proporsi tinggi dan berat badan, mulai timbulnya ciri-ciri seks sekunder, kecenderungan ambivalensi, antara keinginan menyendiri dengan keinginan bergaul, serta keinginan untuk bebas dari dominasi dengan kebutuhan bimbingan dan bantuan dari orangtua, senang membandingkan 
kaedah-kaeadah, nilai-nilai etika atau norma dengankenyataan yang terjadi dalam kehidupan orang dewasa, mulai mempertanyakan secara skeptis mengenai eksistensi dan sifat kemurahan dankeadilan Tuhan, reaksi dan ekspresi emosi masih labil, mulai mengembangkan standar dan harapan terhadap perilaku diri sendiriyang sesuai dengan dunia sosial, Kecenderungan minat dan pilihan karir relatif sudah lebih jelas.

Siswa yang mempunyai keterampilan berinteraksi yang baik, akan memiliki banyak teman dan diterima dalam lingkungannya. Sebaliknya, siswa yang tidak memiliki keterampilan berinteraksi, akan terisolasi, merasa minder, dan tidak percaya diri. Seperti yang dikemukakan oleh Sustisna (2010) bahwa tanpa adanya rasa percaya diri yang tertanam dengan kuat didalam jiwa anak (siswa), pesimisme dan rasa rendah diri akan dapat menguasai dengan mudah.

Kepercayaan diri merupakan salah satu aspek kepribadian yang penting dalam masa perkembangan remaja ( Walgito, 2000; Fitri dkk, 2018). Kepercayaan diri adalah suatu keyakinan dalam diri seseorang bahwa dia memiliki kekuatan, kemampuan dan keterampilan yang sebenarnya didasari pada perasaan positif dan harga diri untuk mencapai kesuksesan berpijak pada usaha sendiri (maesaroh, 2010).

Kepercayaan diri berperan dalam memberikan sumbangan yang bermakna dalam proses kehidupan seseorang. Kepercayaan diri merupakan salah satu modal utama kesuksesan untuk menjalani hidup penuh optimisme dan kunci kehidupan berhasil dan bahagia (Leman, 2000; Taylor, 2009; Fitri dkk, 2018).

Peran layanan Bimbingan dan Konseling di sekolah merupakan usaha untuk membantu peserta didik dalam pengembangan hidup pribadi, kehidupan sosial, kegiatan belajar, serta perencanaan dan pengembangan karir. Seorang guru bimbingan dan konseling di sekolah adalah seorang pengajar atau pendidik yang memegang tanggung jawab memberikan bantuan kepada peserta didik dalam menghindari atau mengatasi kesulitan di dalam kehidupannya agar individu dapat mencapai kesejahteraan hidup. Salah satu upaya yang dapat ditempuh oleh guru bimbingan dan konseling sebagai seorang pembimbing di sekolah terhadap kepercayaan diri siswa dalam kegiatan pendidikan melalui layanan bimbingan konseling ini merupakan alternatif strategis untuk meningkatkan pribadi sosial peserta didik.

Konstelasi perubahan kepribadian peserta didik sangat membutuhkan bimbingan maupun konseling untuk meminimalisir atau membantu peserta didik untuk percaya diri. Bimbingan dan konseling yang di maksud adalah bimbingan dan konseling yang dilaksanakan dalam lingkup pendidikan. Oleh karena itu, proses pelaksanaan bimbingan dan konseling efektif dilakukan secara terprogram, sehingga pelaksanaan bimbingan dapat terlaksana secara optimal.

Melalui pemahaman dan penguasaan yang mendalam tentang asumsi pokok program Bimbingan dan Konseling yang bersifat komprehensif dan penjabaran dalam komponen-komponen program, maka konselor diharapkan dapat menyusun dan mengembangkan rencana aksi layanan Bimbingan dan Konseling dengan tujuan dan target terukur serta berdasarkan skala prioritas layanan yang sesuai dengan kebutuhan peserta didik. Sebagaimana telah dijelaskan sebelumnya bahwa seorang konselor harus menyadari sepenuhnya bahwa tujuan- tujuan yang akan ditetapkan dalam perencanaan program Bimbingan dan Konseling harus menjadi bagianintegral dari tujuan pendidikan nasional pada umumnya dan visi/misi yang ada di sekolah secara khusus, dengan demikian petugas Bimbingan dan Konseling mampu dengan tepat menentukan bagaimana cara yang efektif untuk mencapai tujuan beserta sarana-sarana yang diperlukannya. 
Upaya meningkatkan kepercayaan diri siswa melalui layanan konseling kelompok pendekatan client centered merupakan salah satu pendekatan bimbingan dan konseling yang lebih menekankan pada aktivitas siswa dan tanggung jawab siswa sendiri. Sebagi bersar proses konseling diletakan dipundak siswa sendiri dalam memecahkan masalah yang mereka hadapi, dan konselor hanya sebagai patner untuk mencarai serta menemukan cara yang terbaik dalam memecahkan maslah siswa. Sedangkan standar kompetensi program konseling kelompok yang ingin di capai dalam program konseling kelompok antara lain adalah siswa mampu mengatasi maslaha yang dihadapinya, siswa mampu untuk percaya diri, siswa bisa berinteraksi dengan baik dimasyarakat, siswa dapat bersosialisasi dengan teman-teman dan guru disekolah serta siswa mampu meningkatkan prestasi belajar di sekolah.

Berdasarkan hasil temuan dilapangan, cukup banyak maslah yang dialami oleh siswa sehingga tindakan yang sesuai dilakukan adalah melakukan penelitian selanjutnya ditempat yang sama. Dari urian diatas maka peneliti tertarik untuk melakukan penelitian tentang meningkatkan kepercayaan diri siswa kelas VIII di SMP N 16 Yogyakarta dengan judul:

"Efektifitas Layanan Konseling Kelompok Dengan Pendekatan Client centered Untuk Meningkatkan Kepercayaan diri Pada siswa kelas VIII di SMP N 16 Yogyakarta".

\section{METODE PENELITIAN}

Penelitian ini menggunakan penelitian kuantitatif eksperimen,yaitu penelitian Desain eksperimen pada penelitian ini menggunakan tipe one-Group Pretest-posttest Design. Pada desain ini terdapat pretest, sebelum diberi pelakuan. Dengan demikian hasil pelakuan dapat diketahui lebih akurat, karena dapat membandingkan dengan keadaan sebelum diberi pelaksanaan. (Sugiono, 2013:74).

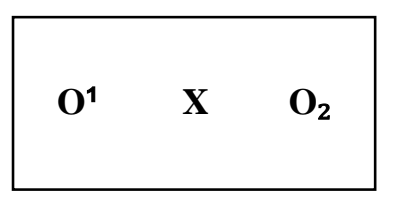

Gambar 1.

Desain Pree test dan Post Test

Keterangan,

$\mathrm{O} 1$ = Nilai Pretest (pengukuran pertama tingkat kepercayaan diri siswa sebelum dilaksanakan konseling kelompok dengan pendekatan client centered

$\mathrm{X}=$ Pelakuan (Pelaksanaan layanan konseling kelompok dengan pendekatan client centered.

$\mathrm{O} 2$ = Nilai Posttest (pengukuran kedua tingkat kepercayaan diri siswa sesuadah diberikan layanan konseling kelompok dengan pendektan client centered.

Untuk mendapatkan data yang akurat dan dapat dipertanggung jawabkan maka perlu metode pengumpulan data yang baik. Penentu metode pengumpulan data dikaitkan dengan variabel yang diungkap datanya. Variabel yang ingin diungkap datannya dalam penelitian ini yaitu variabel meningkatkan kepercayaan diri. Dalam penelitian ini akan digunakan dalam pengumpulan data dengan kuesioner angket.

Sugiyono (2011:119) menyatakan "kuesioner merupakan teknik pemgumpulan data yang dilakukan dengan cara memberi seperangkat pertanyaan tertulis kepada responden untuk menjawabnya". Dalam penelitian ini kuisioner digunakan untuk 
mengumpulakan data dari para responden yang telah ditentukan. Kuisioner berisi pertanyaan yang menyangkut tentang kepercayaan diri siswa kelas VIII SMP N 16 Yogyakarta tahun ajaran 2018/2019. Pertanyaan disusun dengan memperhatikan prinsip-prinsip penulisan angket seperti isi dan tujuan pertanyaan, bahasa yang digunakan, tipe dan bentuk pertanyaan, panjang pertanyaan, urutan pertanyaan, penampilan fisik angket dan sebagainya.

Menurut Sugiyono (2011:142) "dengan adanya kontak langsung antara peneliti dengan responden akan menciptakan suatu kondisi yang cukup baik, sehingga responden dengan sukarela akan memberikan data obyektif dan cepat". Sebab karena itu, peneliti melakukan kontak langsung dengan responden. Penelitian ini, peneliti menggunakan angket yang disajikan dengan serangkayan alternatif dan responden cukup memberi tanda silang, melingkar, ataupun mencentang (sesuai permintaan) pada jawaban yang dianggap sesuai dengan keadaan dirinya.

Waktu penelitan kurang lebih 2 bulan dengan kegiatan antara lain : penelitian pendahuluan, pengembangan istrumen, dan pelaksanaan layanan. Tempat Penelitian dilaksanakan di SMP N 16 yogyakarta dengan waktu pelaksanaan penelitian pada semester genap tahun ajaran 2018/2019.

Dalam sebuah penelitian, subyek penelitian merupakan kedudukan yang sentral, karena pada saat penelitian itulah data dan variabel yang ada diteliti dan diamati oleh peneliti. Pada umumny, peneliti menginginkan untuk melihat subjek penelitian yang cukup banyak agar data yang diperoleh cukup banyak pula. Namun karena berbagai keterbatasan maka peneliti membatasi bebasnya subjek penelitian. Oleh karena itu peneliti menentukan sampel penelitian

Sugiono (2010:117). Populasi adalah wilayah generalisasi yang terdiri atas subjek/obyek yang ditetapkan oleh peneliti untuk dipelajari dan kemudian ditarik kesimpilan. Arikunto (2013:173). Mengatakan bahwa populasi adalah keseluruhan subyek penelitian adalah individu-individu yang diteliti, yang menjadi responden. Populasi dalam penelitian ini adalah siswa SMP N 16 Yogyakarta tahun ajaran 2018/2019 yang berjumlah 236 siswa, seperti yang dijelaskan dalam table dibahawah ini:

Tabel 1.

Jumlah siswa kelas VIII SMP N 16 Yogyakarta Tahun anjaran 2018/2019.

\begin{tabular}{|c|c|c|}
\hline No. & $\begin{array}{c}\text { Nama } \\
\text { Kelas }\end{array}$ & $\begin{array}{c}\text { Jumlah } \\
\text { Siswa }\end{array}$ \\
\hline 1. & VIII A & 34 \\
2. & VIII B & 33 \\
3. & VIII C & 34 \\
4. & VIII D & 34 \\
5. & VIII E & 34 \\
6. & VIII F & 34 \\
7. & VIII G & 33 \\
\hline \multicolumn{2}{|c|}{ Jumlah } & 236 \\
\hline
\end{tabular}



berikut:

Dari 236 siswa tersebut, mempunyai karakteristik yang homogen yaitu sebagai

a. Dari segi usia, mereka tergolong dalam usia remaja awal sekitar 14-15 tahun.

b. Dari sisi pendidikan mereka sama-sama duduk di kelas VIII SMP N 16 Yogyakarta yang merupakan tahap transisi dari kelas VII ke kelas VIII yang masih dalam penyesuaian dengan teman baru.

Pengambilan sampel adalah proses memilih sejumlah elemen secukupnya dari popilasi, sehingga peneliti terhadap sampel dan pemahaman tentang sifat atau karakteristiknya akan membuat kita dapat menggeneralisasikan sifat atau karakteristik tersebut pada elemen populasi.

Menurut Arikunto (2006:134) apabil subyek lebih dari 100, lebih baik diambil semua sehingga penelitinya merupakan peneliti populasi. Selanjutnya jika jumlah subyeknya besar (lebih dari 100 orang) maka dapat diambil antara $10-15 \%$ atau $20-25 \%$ atau lebih tergantung setidak-tidaknya dari :

a. Kemampuan peneliti (dilihat dari waktu, tenaga dan dana).

b. Sempit luasnya wilayah pengamatan dari setiap objek, karena hal ini menyangkut banyak sedikitnya data.

c. Besar kecilnya resiko yang ditanggung oleh peneliti untuk penelitian yang resikonya besar, tentu saja jika resikonya besar hasilnya akan lebih baik. (Arikunto,2006:134).

Sampel yang digunakan dalam penelitian ini yaitu berjumalah 7 siswa. Agar pelaksanaan layanan konseling kelompok pendektan client centered lebih menghemat waktu, karena dalam 1 jam pelajaran hanya 35 menit. Teknik sampel yang digunakan yaitu teknik sampling. Instrumen yang digunakan dalam penelitian ini adalah kuisoner atau angket. Penelitian ini menggunakan teknik penelitian pre-eksperimental design dengan pola eksperimen one group pre-test and post-test design. Pengujian akan dilakukan dengan menggunakan aplikasi SPSS (Staristical Package for Social Sciense) dengan uji paired T-Test.

\section{HASIL PENELITIAN DAN PEMBAHASAN Profil Umum Kepercayaan Diri Siswa}

Kepercayaaan diri merupakan salah satu modal yang harus ditumbuhkan pada diri setiap siswa, agar kelak mereka mampu menjadi manusia yang bisa mengontrol berbagai aspek yang ada pada dirinya. Melalui kemampuan tersebut siswa akan lebih jernih dalam mengatur tujuan dan sasaran pribadi yang jelas, serta akan lebih mampu dalam mengarahkan perilaku menuju keberhasilan dan kesuksesan

Tabel 2.

Kategori Skor Kepercayaan Diri

\begin{tabular}{|c|c|c|c|}
\hline Kelas Interval & Kategori & Frekuensi & $(\%)$ \\
\hline $164 \leq \mathrm{x}<216$ & Tinggi & 38 & $\begin{array}{c}16,10 \\
\%\end{array}$ \\
\hline $108 \leq \mathrm{x}<163$ & Sedang & 151 & $64 \%$ \\
\hline $54 \leq \mathrm{x}<108$ & Rendah & 47 & $19,9 \%$ \\
\hline \multicolumn{2}{|c|}{ TOTAL } & 236 & $100 \%$ \\
\hline
\end{tabular}


Berdasarkan table 4.1 dengan grafik 4.1 tampak bawah semua populasi dari kelas VIII A, B, C, D, E, F, dan G, yang ada pada kategori tinggi terdapat 38 siswa dengan presentase $16,10 \%$ pada kategori sedang 151 siswa dengan presentase $64 \%$ dan pada kategori rendah 47 siswa dengan presentase 19,9\% Hal ini dimaksudkan bawah profil kepercayaan diri secara umum untuk siswa kelas VIII memiliki kepercayaan diri yang sedang, dilihat dari hasil presentase di atas.

\section{Profil Aspek Kepercayaan Diri Siswa}

Setelah mengetahui tingkat kepercayaan diri siswa kelas VIII di SMP N 16 Yogyakarta, dilihat dari gambaran umum kepercayaan diri. Adapun untuk mengetahui rumusan program konseling Pribadi maka harus melihat aspek-aspek mana saja memiliki kategori dari yang tertinggi sampai dengan yang terendah.

Berdasarkan kategorisasi yang telah diketahui bahwa tingkat kepercayaan diri siswa kelas VIII di SMP N Yogyakarta tahun 2018/2019 dikatakan cendrung sedang. Oleh karena itu peneliti melihat lagi kategori aspek-aspek dari kepercayaan diri. Semua aspek yang berada Pada kategori sedang dapat diketahui presentase 74,57\%, 52,96\%, dan 71,18\% dengan aspek optimis, objektif dan rasional Kategori tinggi dapat diketahui dengan presentase $64,83 \%, 80,50 \%, 82,62 \%$ dan 66,94\% terdiri dari aspek fleksibel, bertoleransi, keyakinan kemampuan diri, dan bertanggung jawab.

\section{Indikator Profil kepercayaan Diri}

Dibawah dari 14 indikator kepercayaan diri total frekuensi 236 yang ada pada kategori rendah, sedang, dan tinggi dengan jumlah presentase yang berbeda-beda. Hal ini dimaksudkan bahwa indikator paling rendah terdapat di indikator 4 dengan presentase $84,75 \%$ dan indikator paling tinggi di indikator 3 dengan presentase 58,89\%.

\section{Uji Prasarat dan Hipotesis}

\section{Uji Normalitas}

Persyaratan analisis data dilakukan sebagai syarat sebelum peneliti melakukan analisis data. Persyaratan analisis data meliputi uji normalitas sebaran bertujuan untuk mengetahui sebaran tiap variabel berdistribusi normal atau tidak. Untuk mengetahui normalitas sebaran digunakan rumus Shapiro Wilk karena jumlah responden kurang dari 30, dengan kriteria $\mathrm{p}>0,05$ berarti data berdistibusi normal.

Berdasarkan hasil uji normalitas menggunakan Shapiro Wilk diperoleh hasil sebaran skor sebelum diberikan treatment dengan nilai $=0,434$ dan setelah diberikan treatment diperoleh $=0,927$. Berdasarkan tabel di atas maka masing-masing variabel diperoleh nilai $\mathrm{p}>0,05$ maka sebaran data berdistribusi normal.

\section{Uji Homogenitas}

Uji Homogenitas dilakukan untuk mengetahui varian populasi data antara dua kelompok atau lebih terkait dengan kepemilikan varian yang sama atau berbeda. Uji Homogenitas dilakukan terhadap hasil angket antara pretest dan posttest. Perhitungan uji homogenitas dilakukan sebagai prasyarat dalam uji hipotesis, yaitu Independent Sample T Test yang terdapat pada fasilitas SPSS 16.

Dari hasil Output dapat diketahui bahwa nilai Sig. untuk nilai kepercayaan diri pretest dan posttest adalah 0,147. Karena nilai signifikasi lebih dari $\mathrm{p}>0,05$ maka Ho diterima. Jadi nilai kepercayaan diri pretest dan posttest bervarian sama dan telah memenuhi asumsi dasar homogenitas. 


\section{Uji T-tes}

Perhitungan uji paired t-test dalam penelitian ini menggunakan program komputer yaitu SPSS (Statistical Package for Sosial Sciens) versi 16.0 for windows dengan uji paired T-test. perbedaan rerata antara pre test dan post test. Rerata pre test sebelum diberikan layanan 101,28 sedangkan rerata post test setelah diberikan layanan sebesar 155,42 . Selisih antara angket kepercayaan diri siswa sebelum dan sesudah treatment sebesar 54.14.

Berdasarkan hasil analisis dengan bantuan program SPSS (Statistical Package for Sosial Sciens) Versi 16.0 for Windows diperoleh nilai $t=20,29$ dengan nilai $p=0,000$ $<0,05$ berarti pemberian layanan konseling kelompok menggunakan pendekatan client centered efektif untuk meningkatkan rasa percaya diri pada siswa.

\section{Hipotesis}

Dari hasil analisis uji t diperoleh nilai $\mathrm{t}=20,297$ dengan nilai $\mathrm{p}=0,000<0,05$. Berdasarkan uji $\mathrm{t}$ dengan kriteria $\mathrm{p}<0,05$ maka hipotesis yang diajukan dinyatakan terbukti dan signifikan.

Hipotesis yang diajukan pada penelitian ini adalah (Ha) yang berbunyi "Kepercaya diri dapat ditingkatkan dengan menggunakan konseling kelompok pendekatan client centered pada siswa kelas VIII SMP N 16 Yogyakarta. Tahun Pelajaran 2018/2019". Dengan selisih antara angket kepercayaan diri sebelum dan sesudah diberikan treatment sebesar 54,1429, berarti pemberian konseling kelompok menggunakan pendekatan client centered efektif meningkatkan rasa percaya diri pada siswa.

\section{Profil Umum Kepercayaan Diri Siswa}

Berdasarkan hasil penelitian mengenai kepercayaan diri pada siswa kelas VIII SMP N 16 yogyakarta tahun ajaran 2018/2019. Kepercayaan diri adalah salah satu aspek kepribadian yang penting pada seseorang tanpa adanya kepercayaan diri akan banyak menimbulkan masalah pada diri seseorang. Kepercayaan diri merupakan atribut yang paling berharga pada diri seseorang dalam kehidupan bermasyarakat. Dikarenakan dengan kepercayaan diri, seseorang mampu mengaktualisasikan segala potensi dirinya. Kepercayaan diri diperlukan baik oleh seorang anak maupun orang tua, secara individual maupun kelompok.

Abraham Maesaroh mengatakan bahwa kepercayaan diri adalah suatu keyakinan dalam diri seseorang bahwa dia memiliki kekuatan, kemampuan dan keterampilan yang sebenarnya didasari pada perasaan positif dan harga diri mencapai kesuksesan berpijak pada usahanya sendiri (Suwarjo dan Eliasa, 2010:74).

Namun masih terdapat siswa yang mempunyai kepercayaan diri yang sedang, dilihat dari profil kepercayaan diri secara umum siswa kelas VIII yang dilihat dari hasil presentase kepercayaan diri masih tergolong sedang, dengan jumlah responden 236 siswa, terdapat frekuensi 151 dari jumlah presentase 64\% Sedangkan anak yang mempunyai kategori kepercayaan diri tinggi terdapat frekuensi 38 dengan jumlah presentase 16,10\% dan kategori rendah terdapat frekuensi 47 dari julah responden 236 dengan presentase $19,9 \%$.

Tampak bawah dari semua variabel yang berada pada kategori rendah dengan frekuensi 236 dapat diketahui present 27,11\% Pada kategori sedang dapat diketahui dengan presentase 44,97, 41,78 , 47,03 dan 40,88. Kategori tinggi dapat diketahui dengan presentase $80,50 \%, 82,62 \%$ dan $66,94 \%$ terdiri dari aspek fleksibel, bertoleransi 
dan keyakinan kemampuan diri 14 indikator kepercayaan diri total frekuensi 236 yang ada pada kategori rendah, sedang, dan tinggi dengan jumlah presentase yang berbedabeda. Hal ini dimaksudkan bahwa indikator paling rendah terdapat di indikator 4 dengan presentase $84,74 \%$ dan indikator paling tinggi di indikator 3 dengan presentase $58,89 \%$.

Dari jumlah siswa yang memiliki kepercayaan diri rendah peneliti mengambil sampel 7 siswa. Agar pelaksanaan layanan konseling kelompok dengan pendekatan client centered lebih efektif dan menghemat waktu, karena dalam satu jam pelajaran hanya 35 menit. Peneliti menggunakan teknik random sampling dengan pola eksperimen one gruoup pre-test dan post-test design untunk meningkatkan kepercayaan diri siswa.

\section{Efektifitas Layanan Konseling Kelompok Dengan Pendekatan Client Center Untuk Meningkatkan Kepercayaan Diri Siswa}

Berdasarkan hasil peneliti menunjukkan hipotesis terbukti bahwa kepercaya diri dapat ditingkatkan dengan menggunakan konseling kelompok pendekatan client centered pada siswa kelas VIII SMP N 16 Yogyakarta Tahun Pelajaran 2018/2019. Dari hasil uji-t yang dilakukan di peroleh nilai $\mathrm{t}=20,297$ dengan nilai $\mathrm{p}=0,000<0,05$ maka hipotesis yang di ajukan diterima dan signifikan, berarti pemberian konseling kelompok dengan pendekatan client centered efektif untuk meningkatkan rasa percaya diri pada siswa.

Tujuan layanan konseling kelompok pendekatan client centered adalah berkembangnya perasaan, pikiran, persepsi, wawasan, sikap kemampuan untuk berkomunikasi dan bersosialisasi, anggota kelompok serta terpecahnya masalah anggota kelompok sehingga anggota kelompok dapat berkembang secara optimal serta untuk meningkatkan kepercayaan diri siswa. Kepercayaan diri dapat ditinjau dalam kepercayaan diri lahir dan batin yang diimplementasikan.

Hasil perhitungan tes skala kepercayaan diri menunjukan bahwa kepercayaan diri siswa tergolong rendah, hasil pengamatan awal (studi pendahuluan saat PPL) menunjukan bahwa kepercayaan diri siswa termasuk kurang, ini mengindikasikan bahwa kepercayaan diri pada siswa tidak selalu sama, pada saat tertentu siswa merasa mempunyai kepercayaan diri atau mungkin tidak, ada situasi dimana siswa merasa mempunyai kepercayaan diri dan situasi di mana siswa tidak merasa demikian. Seperti yang dikemukakan oleh Angelis (2003:13) bahwa: "Kpercayaan diri itu tidak bisa disama-ratakan dari satu aktifitas ke aktifitas lainnya".

Berdasarkan analisis data menunjukkan bahwa ada perbedaan tingkat kepercayaan diri siswa antara sudah diberikan layanan dan belum mendapatkan layanan konseling kelompok dengan pendekatan client centered. Hasil penelitian menunjukkan bahwa rata- rata tingkat kepercayaan diri siswa pada kelas VII1 SMP N 16Yogyakarta Tahun Pelajaran 2018/2019 setelah melihat profil kepercayaan diri dan memberikan layanan konseling kelompok dengan pendekatan client centered. lebih tinggi dibanding sebelum mendapatkan layanan konseling kelompok.

Kepercayaan diri pada dasarnya adalah sikap yang memungkinkan individu untuk memiliki persepsi positif dan realistis tentang diri sendiri dan kemampuan diri (Goel dan Anggarwa: 2012). Peserta didik yang memiliki kepercayaan diri, mereka akan memiliki keyakinan bahwa mereka mempunyai suatu kekuatan dalam diri untuk meraih keberhasilan yang sesuai dengan kemampuan yang mereka miliki.

Adapun kemampuan yang harus dimiliki siswa adalah mampu menyesuaikan diri dengan lingkungan, selalu berfikir positive, tidak mudah menyerah, mentaati peraturan, 
bertanggung jawab dan berusaha untuk berprestasi. Semua itu berpijak pada usaha sendiri dan dapat mengenal kekurangan dan kelebihan diri. Peserta didik yang memiliki kepercayaan diri dapat menyelesaikan tugas atau pekerjaan yang sesuai dengan tahap perkembangannya dengan baik atau setidaknya memiliki kemampuan untuk belajar cara-cara menyelesaikan tugas tersebut.Sebelum adanya layanan konseling kelompok (pre-test), siswa mempunyai presentase 10,87 tingkat kepercayaan diri terdapat 7 siswa kategori rendah. Menunjukkan bahwa karakteristik sikap kepercayaan diri yang dimiliki siswa belum bagus namun masih bisa ditingkatkan dengan mengunakan layanan konseling kelompok pendekatan client centered. Pemberian layanan konseling kelompok dengan pendekatan client centered setelah diberikan pos-test mempunyai tingkat kepercayaan diri siswa berada pada kategori tinggi, Ini mengindikasikan sudah ada peningkatan dalam karakteristik kepercayaan diri yang dimiliki siswa.

Layanan konseling kelompok pendekatan client centered pada dasarnya adalah layanan konseling perorangan yang dilaksanakan dalam suasana kelompok, bertujuan untuk membantu kepribadian konseli secra integral, berdiri sendiri dan mempunyai kemapuan untuk memecahkan masalah sendiri. Didalam konseling kelompok terdapat pemimpin kelompok (konselor) dan anggota kelompok (konseli). Dalam proses konseling kelompok terjadi hubungan konseling dalam suasana yang diusahakan sama seperti konseling individual yaitu hangat, terbuka dan penuh keakraban. Selain itu terdapat pengungkapan dan pemahaman masalah konseli, penelusuran sebab-sebab timbulnya masalah, upaya pemecahan masalah jika diperlukan menggunakan metodemetode khusus, evaluasi dan tindak lanjut.

Menurut Prayitno (2013:311).Konseling kelompok pada dasarnya adalah layanan konseling perorangan yang dilaksanakan di dalam suasana kelompok. Di sana ada konselor (yang jumlahnya mungkin lebih dari seorang) dan ada klien, yaitu para anggota kelompok (yang jumlahnya paling kurang dua orang). Disana terjadi hubungan konseling dalam suasana yang diusahakan sama seperti dalam konseling perorangan, yaitu hangat terbuka, permisif, dan penuh keakraban.

Beberapa hasil penelitian mengungkapkan sebagian besar kepercayaan diri remaja berada pada kategori rendah artinya, perlunya upaya untuk meningkatkan kepercayaan diri remaja. Akan tetapi, sebelum melakukan upaya untuk meningkatkan kepercayaan diri pada remaja, sebaiknya terlebih dahulu dikenali sumber penyebab timbulnya kurang kepercaya diri pada siswa. Hal tersebut dapat dijadikan titik tolak ukur untuk menangulangi rasa kurang percaya diri pada remaja.

Siswa dituntut untuk memiliki kepercaya diri secara optimal agar mereka menjadi individu yang mampu bersosialisasi dengan baik kepada seluruh kalangan baik yang muda maupun yang tua. Siswa juga harus memilki pemikiran rasional dan realistis atau bisa menerima kenyataan apa yang telah terjadi pada diri mereka. Siswa juga dituntut untuk menjadi individu yang bertanggung jawab, karena menumbuhkan rasa tanggung jawab pada siswa sejak dini, itu untuk melatihkan mereka menjadi sosok individu yang beribawa dan mentaati norma dan nilai yang berlaku di masyarakat. Siswa harus menanamkan rasa tanggung jawab pada diri masing-masing, adapun tanggung jawab siswa sebagai pelajar adalah belajar dengan baik, mengerjakan tugas sekolah yang sudah diberikan, dan disiplin menjalani tata tertib disekolah.

Berdasarkan grafik diatas diperoleh hasil rata-rata angket variabel kepercayaan diri tiap aspek sebelum dan sesudah diberikan treatment meningkat. Dilihat dari aspek fleksibel mendapatkan nilai meningkat sebelum diberikan treatment diperoleh angka sebesar 15,11 dan sesudah diberikan treatment diperoleh angka sebesar 23,33. Aspek 
Bertoleransi sebelum diberikan treatment diperoleh angka sebesar 13,44 dan sesudah treatment diperoleh angka sebesar 22,67. Aspek Kemampuan keyakinan diri sebelum diberikan treatment diperoleh angka sebesar 13,29 meningkat sesudah diberikan treatment diperoleh angka sebesar 20,43. Aspek Optimis sebelum diberikan treatment diperoleh angka sebesar 12,14 dan meningkat sesudah diberikan treatment diperoleh angka sebesar 16 .

Aspek Objektif diperoleh angka sebelum diberikan treatment sebesar 11,43 dan sesudah diberikan treatment diperoleh angka sebesar 15,14. Aspek Bertanggung jawab diperoleh angka sebelum diberikan treatment sebesar 12,75 meningkat sesudah diberikan treatment diperoleh angka sebesar 20,50. Aspek Rasional dan realistis diperoleh angka sebelum diberikan treatment sebesar 13,14 dan sesudah diberikan treatment diperoleh angka sebesar 21,29.

Berdasarkan hasil sebelum dan sesudah treatment dengan diberikannya layanan konseling kelompok pendekatan client centered diperoleh peningkatkan aspek kepercayaan diri tertinggi yaitu aspek bertoleransi yaitu dari 13,44 meningkat 22,67. Berdasarkan rata-rata kepercayaan diri siswa secara keseluruhan yang diperoleh sebelum diberikan treatment sebesar 101,28 dan sesudah diberikan treatment diperoleh angka sebesar 155,42 .

Jadi dengan diberikannya layanan konseling kelompok pendekatan client centered adalah agar siswa mampu mengatur atau mengarahkan perilakunya agar berkembang perasaan, pikiran, persepsi, wawasan, sikap kemampuan untuk berkomunikasi dan bersosialisasi dengan memiliki pengelolaan diri yang baik. Berdasarkan hasil tersebut dapat disimpulkan bahawa konseling kelompok menggunakan pendekatan client centered efektif untuk meningkatkan kepercayaan diri siswa kelas VIII di SMP N 16 Yogyakarta tahun pelajaran 2018/2019.

\section{DAFTAR PUSTAKA}

Angelis, De Barbara 2005. Confidence, Percaya Diri Sumber sukses dan Kemandirian. Jakarta:PT. Gramedia. Pustaka Utama.

Anita Lie.2004.101 Cara Menumbuhkan Percaya Diri Anak. Jakarta: PT.Elex Media Komputindo kelompok Gramedia.

Arikunto, Suharsimi. 2002. Prosedur Penelitian Suatu Pendekatan Praktek.Jakarta: Rineka Cipta.

Ali, Mohammad. 2014. Psikologi Remaja. Jakarta: Bumi Aksara.

Ashriati N. Alsa, A dan Suprihatin T. 2006. "Hubungan Antara Dukungan Sosial Orang Tua dengan Kepercayaan Diri Remaja Penyandang Cacat Fisik pada SLB-D YPAC Semarang”. Jurnal Psikologi Proyeksi. Vol.1, No.2.

Aswi Mastuti. 2008. 50 Kiat Percaya Diri. Jakarta. PT. Buku Kita.

Azwar, Saifuddin. 2010. Penyusunan Skala Psikologi. Yogyakarta: Pustaka Pelajar. 
Corey, Gerald. 2005. Teori dan Praktek Dari Konseling dan Psikoterapi. Bandung: PT. Refika aditama.

Dani Tohir. 2016. “ Program Bimbingan Pribadi Sosial Untuk Meningkatkan Kepercayaan Diri Siswa”. Jurnal Of Regional Public Administration. Vol.1, No.1.

Darmawan, D. 2013. Metode Penelitian Kuantitatif. Bandung: PT Remaja Rosdakarya.

Endah Rahayuningdiyah. 2016. “Upaya Meningkatkan Kepercayaan Diri Melalui Layanan Konseling Kelompok Pada Siswa Kelas VIII D SMP Negeri 3 Ngrambe. JIPE. Vol.1, No.1.

Fitri, E. Zola, N. dan Ifdil, I. 2018. “ Profil Kepercayaan Diri Remaja Serta FaktorFaktor yang Mempengaruhi. Jurnal Penelitian Pendidikan Indonesia. Vol.4, No.1.

Ghufron, N. Rismawati, R. 2010. Teori-Teori Psikologi. Yogyakarta: Ar-ruzz Grub.

Gerald Coret. 2013. Teori dan Praktik Konseling Psikoterapi.Bandung. PT Rifka Aditama.

Goel, M. Aggarwal, P. 2012." A Comparative Study Of Self Confidence Of Single Child and Child With Sibling". Jurnal Internasional. Vol.2, No.3.

Hakim Thursan. 2012. Mengatasi Rasa Tidak Percaya Diri. Jakarta. Puspa swara.

Hakim, Thursan. 2002. Mengatasi Rasa Tidak Percaya Diri. Jakarta:Puspa Swara.

Ibnu Ardi. 2014. Hubungan Antara Kepercayaan Diri Dengan Penyesuaian Sosial Pada Siswa Kelas X Di Smk Negeri 1 Kalasan. Disertai tidak diterbitkan. Yogyakarta. Universitas Negeri Yograkarta.

Kurnanto, M.Edi. 2014. Konseling Kelompok. Bandung: Alfabeta.

Komalasari, Gantina. dkk. 2016. Teori dan Teknik Konseling. Jakarta.PT Indeks.

Mastuti, Indari. 2008. 50 Kiat Percaya diri. Jakarta: Hi-Fest Publishing.

Lauser, P. 2007. Tes Kepribadian. Jakarta. Bumi Asara.

Manisha Goel dan Aggarwal, P. 2012." A Comparative Study Of Self Confidence Of Single Child and Child With Sibling”. Jurnal Internasional. Vol.2, No.3.

Narbuko, Cholid. 2009. Metodologi Penelitian. Jakarta: Bumi Aksara.

Nazir, Moh. 2014. Metode Penelitian. Bogor: Ghalia Indonesia.

Prayitno \& Amti Erman. 2004. Dasar-Dasar Bimbingan Dan Konseling. Jakarta:Rineka Cipta. 
Percaya Diri : Panduan Bagi Remaja yang Masih Mencari Jadi Dirinya.Jakarta: PT Elex Media Komputindo.

Prayitno. 1995. Layanan Bimbingan Dan Konseling Kelompok (Dasar dan Profil). Jakarta: Ghalia Indonesia.

Rahayuningdiyah, E. 2016. “Upaya Meningkatkan Kepercayaan Diri Melalui Layanan Konseling Kelompok Pada Siswa Kelas VIII D SMP Negeri 3 Ngrambe. JIPE. Vol.1, No.1.

Riduwan.2005. Belajar Mudah Penelitian untuk Guru, Karawan dan Peneliti Pemula: Bandung: Alfabeta.

Suhardita, K. 2011. "Efektivitas Penggunaan Teknik Permainan dalam Bimbingan Kelompok untuk Meningkatkan Kepercayaan Diri Siswa". Bandung: Universitas Pendidikan Indonesia. Edisi Khusus No.1.

Sugiyono. 2018. Metode Penelitian Kuantitatif. Bandung: CV Alfabeta.

Sugiyono. 2010. Metode penelitian kuantitatif kualitatif dan R \& D. Bandung: Alfabeta. Suharsimi Arikunto. 2013. Prosedur Penelitian Suatu Pendekatan Praktik. Jakarta: PT Rineka Cipta 